\title{
Regulation of Octn2 Transporter (SLC22A5) by Peroxisome Proliferator Activated Receptor Alpha
}

\author{
Tomoji Maeda, ${ }^{a}$ Takeru Wakasana, ${ }^{a}$ Miho Funabashi,${ }^{a}$ Akimasa Fukushi,${ }^{a}$ Masaharu Fujita,${ }^{a}$ \\ Kiyoto Mотоліма, ${ }^{b}$ and Ikumi TAMAI*,a \\ ${ }^{a}$ Department of Membrane Transport and Pharmacokinetics, Faculty of Pharmaceutical Sciences, Tokyo University of \\ Science; 2641 Yamasaki, Noda, Chiba 278-8510, Japan: and ${ }^{b}$ Department of Biochemistry, Meiji Pharmaceutical \\ University; 2-522-1 Noshio, Kiyose, Tokyo 204-8588, Japan. \\ Received January 16, 2008; accepted March 8, 2008; published online March 14, 2008
}

The tissue distribution and disposition of carnitine, which plays an important role in the transport of longchain fatty acids across the mitochondrial inner membrane for $\beta$-oxidation, are well controlled by carnitine transporter organic cation/carnitine transporter 2 (OCTN2). Since little information is available on regulation of the expression of the OCTN2 gene, we examined the factors that affect the expression level of rat Octn2 (rOctn2), focusing on nuclear receptor peroxisome proliferator activated receptor alpha (PPAR $\alpha$ ), which regulates expression of genes associated with $\beta$-oxidation of fatty acids. mRNA of rOctn 2 was induced by the PPAR $\alpha$ ligand fenofibrate in primary-cultured rat hepatocytes. Further, the PPAR $\alpha$ ligand Wy14643 increased the expression of Octn2 in wild-type mice, but not in PPAR $\alpha$ knockout mice. Analysis of the rOctn2 promoter region suggested the presence of putative cis elements of PPAR $\alpha$. Wistar rats treated with intraperitoneal fenofibrate administration showed increased expression of rOctn 2 mRNA in liver, and uptake of $\left[{ }^{3} \mathrm{H}\right]$ carnitine by freshly isolated hepatocytes derived from those rats was also increased. In conclusion, our results indicate that the nuclear receptor PPAR $\alpha$ directly up-regulates the expression of rOctn2 and increases the hepatic uptake of carnitine via rOctn2.

Key words transporter; carnitine; $\beta$-oxidation; peroxisome proliferator activated receptor alpha

Carnitine plays an important role in the transport of longchain fatty acids across the mitochondrial inner membrane in the form of acylcarnitine esters for $\beta$-oxidation and energy production. Transporters that mediate carnitine transport across the plasma membrane into the cells and enzymes (such as carnitine palmitoyltransferases, CPTs) that conjugate and deconjugate carnitine with long-chain fatty acids play key roles in these processes. In mammals, several carnitine transporters have been isolated and characterized. We reported that organic cation/carnitine transporter (OCTN) 1 and OCTN2 in humans and mice, and OCTN3 in mice, are functional as carnitine transporters. ${ }^{1-3)}$ OCTN2 (SLC22A5) is an $\mathrm{Na}^{+}$-dependent, high-affinity $\left(K_{\mathrm{m}}=4\right.$ to $\left.25 \mu \mathrm{M}\right)$ carnitine transporter, ${ }^{2,3)}$ which serves to maintain carnitine levels in serum by functioning as a reabsorption transporter of carnitine after glomerular filtration. ${ }^{4-6)}$ It was reported that human and mouse OCTN1 transported carnitine, ${ }^{1,7)}$ whereas rat OCTN1 did not. ${ }^{8}$ Human carnitine transporter CT2 and mouse OCTN3, which are present selectively in male reproductive tissues, ${ }^{3,9)}$ transport carnitine with high affinity ( $K_{\mathrm{m}}=20 \mu \mathrm{M}$ and $3 \mu \mathrm{M}$, respectively) in an $\mathrm{Na}^{+}$-independent manner. In addition, Nakanishi et al. ${ }^{10)}$ reported that the $\mathrm{Na}^{+}$and $\mathrm{Cl}^{-}$-coupled neutral and cationic amino acid transporter $\mathrm{ATB}^{0,+}$ can transport carnitine with low affinity $\left(K_{\mathrm{m}}=\right.$ $0.83 \mathrm{~mm}$ ).

A genetic deficit of carnitine transporter activity results in primary systemic carnitine deficiency, the symptoms of which are severe. ${ }^{11)}$ Juvenile visceral steatosis (jvs) mice, which show the phenotype of systemic carnitine deficiency caused by functional loss of OCTN2, exhibit fatty liver, cardiomyopathy and hypoglycemia. ${ }^{12)}$ Therefore, it is possible that impaired expression of OCTN2 is associated with various diseases.

Recently, nuclear receptors have been established to be transcription factors that regulate diverse physiological func- tions, including the expression of enzymes and transporters. Forty-eight members of the nuclear receptor superfamily have been identified in humans. ${ }^{13)}$ Peroxisome proliferator activated receptor (PPAR) $\alpha$ is a nuclear receptor that serves important functions in lipid utilization and inflammation. ${ }^{14,15)}$ Like other members of the nuclear receptor superfamily, members of the PPAR family are activated through ligand binding, which causes changes in receptor conformation, heterodimer formation with the 9-cis-retinoic acid receptor, recruitment of coactivators into a multiprotein complex, and transcriptional regulation of responsive genes. Consistent with known roles of PPAR $\alpha$, downstream genes engaged by this receptor encode for proteins involved in key aspects of lipid metabolism and inflammation. ${ }^{15)}$ In general, activation of PPAR $\alpha$ causes up-regulation of CPT- 1 and CPT- 2 in the liver to enhance $\beta$-oxidation of fatty acids. ${ }^{16,17)}$ Recently, it was reported that the expression of OCTN2 was up-regulated by $\operatorname{PPAR} \alpha$ agonists, such as clofibrate and Wy14643. ${ }^{18)}$ However, it was unclear whether PPAR $\alpha$ directly regulates the expression of Octn 2 and increases carnitine transport activity via rOctn2. Accordingly, in the present study, the regulatory mechanism of OCTN2 expression was characterized, focusing especially on the nuclear receptor $\operatorname{PPAR} \alpha$. We used several methods to examine the association of PPAR $\alpha$ with OCTN2 expression.

\section{MATERIALS AND METHODS}

Materials $\quad \mathrm{L}-\left[{ }^{3} \mathrm{H}\right]$ Carnitine $\quad(80 \mathrm{Ci} / \mathrm{mmol})$ and $\quad[\gamma-$ ${ }^{32} \mathrm{P}$ ]adenosine triphosphate $(3000 \mathrm{Ci} / \mathrm{mmol})$ were purchased from Amersham Pharmacia Biotech (Piscataway, NJ, U.S.A.). All other reagents were purchased from SigmaAldrich (St. Louis, MO, U.S.A.) and Wako Pure Chemicals Industries Ltd. (Osaka, Japan).

Cell Culture and Transfection Fao cells, a subclone of 
rat hepatoma HII4E cells, were cultured in Ham's F12 medium (MP Biomedicals, Morgan, CA, U.S.A.), under the conditions reported previously. ${ }^{19)}$ The mammalian expression vector pCMX-PPAR $\alpha$ was constructed by inserting the cDNA of PPAR $\alpha$ into pCMX. $^{20)}$ Fao cells were seeded at the concentration of $2.5 \times 10^{5}$ cells/well in 6-well plates and were transfected with $0.1 \mu \mathrm{g}$ of total plasmid DNA per well using Lipofectamine 2000 (Invitrogen, Carlsbad, CA, U.S.A.). At $48 \mathrm{~h}$ after transfection, the cells were used for semi-quantitative reverse transcription polymerase chain reaction (RTPCR) as described below.

Animal Male Wistar rats $(200-260 \mathrm{~g}$ body weight) were obtained from Saitama Experimental Animals Supply Co., Ltd. (Saitama, Japan). Male Wistar rats, normal male NZB mice (5-6 weeks of age) and PPAR $\alpha$-null mice ${ }^{21)}$ were housed three per cage with free access to commercial chow and tap water, maintained on a 12-h dark/light cycle (8:00 a.m. - 8:00 p.m. light) in an air-controlled room (temperature, $24.5 \pm 1{ }^{\circ} \mathrm{C}$; humidity, $55 \pm 5 \%$ ). They were handled with humane care under the guidelines for animal experimentation of the Tokyo University of Science or Meiji Pharmaceutical University Committee for Ethics of Experimentation and Animal Care.

Animal Experiments Fenofibrate was administered subcutaneously (s.c.) at a single dose of $100 \mathrm{mg} / \mathrm{kg}$ body weight $(15 \mathrm{mg} / \mathrm{ml}$ in mineral oil) per day for $4 \mathrm{~d}$. The control group received the same volume of vehicle s.c. All studies were performed $24 \mathrm{~h}$ after fenofibrate or vehicle administration. Mice were fed either a control diet (CE7, Clea Japan) or one containing $0.05 \%$ Wy 14643 for $5 \mathrm{~d}$.

Isolation and Cultivation of Rat Hepatocytes Rat hepatocytes were isolated by the collagenase perfusion method as described by Tamai and Tsuji. ${ }^{22}$ Briefly, rats were anesthetized with diethyl ether prior to portal vein cannulation. The liver was perfused in situ with oxygenated EGTA buffer $\left(8.0 \mathrm{~g} / 1 \quad \mathrm{NaCl}, \quad 0.4 \mathrm{~g} / \mathrm{l} \mathrm{KCl}, \quad 0.121 \mathrm{~g} / 1 \quad \mathrm{Na}_{2} \mathrm{HPO}_{4}, \quad 0.06 \mathrm{~g} / \mathrm{l}\right.$ $\mathrm{KH}_{2} \mathrm{PO}_{4}, 0.35 \mathrm{~g} / 1 \mathrm{NaHCO}_{3}, 1.0 \mathrm{~g} / 1$ glucose, $0.06 \mathrm{mg} / 1$ phenol red, $2.383 \mathrm{~g} / \mathrm{l} \mathrm{HEPES}$, and $0.190 \mathrm{~g} / \mathrm{l}$ EGTA) for $3 \mathrm{~min}$, followed by the addition of oxygenated collagenase buffer $\left(8.0 \mathrm{~g} / 1 \mathrm{NaCl}, \quad 0.4 \mathrm{~g} / \mathrm{l} \mathrm{KCl}, \quad 0.121 \mathrm{~g} / 1 \quad \mathrm{Na}_{2} \mathrm{HPO}_{4}, \quad 0.06 \mathrm{~g} / 1\right.$ $\mathrm{KH}_{2} \mathrm{PO}_{4}, 0.2 \mathrm{~g} / 1 \mathrm{MgSO}_{4}, 0.735 \mathrm{~g} / 1 \mathrm{CaCl}_{2}, 0.35 \mathrm{~g} / 1 \mathrm{NaHCO}_{3}$, $1.0 \mathrm{~g} / 1$ glucose, $0.06 \mathrm{~g} / 1$ phenol red, $2.383 \mathrm{~g} / 1 \mathrm{HEPES}$, and $0.5 \mathrm{~g} / 1$ collagense) for an additional $2 \mathrm{~min}$ perfusion. Hepatocytes were isolated and released in $50 \mathrm{ml}$ of ice-cold Hanksbalanced salt solution (HBSS) $(8.0 \mathrm{~g} / 1 \mathrm{NaCl}, 0.4 \mathrm{~g} / 1 \mathrm{KCl}$, $0.121 \mathrm{~g} / \mathrm{l} \quad \mathrm{Na}_{2} \mathrm{HPO}_{4}, \quad 0.06 \mathrm{~g} / 1 \quad \mathrm{KH}_{2} \mathrm{PO}_{4}, \quad 0.2 \mathrm{~g} / 1 \quad \mathrm{MgSO}_{4}$, $0.265 \mathrm{~g} / 1 \mathrm{CaCl}_{2}, \quad 0.35 \mathrm{~g} / 1 \mathrm{NaHCO}_{3}, \quad 1.0 \mathrm{~g} / 1$ glucose, and $0.06 \mathrm{mg} / 1$ phenol red) and were filtered through a sterile nylon mesh (150 mesh). Cell suspensions were centrifuged at $40 \times \mathbf{g}$ for $3 \mathrm{~min}$ at room temperature. The resultant cell pellet was washed and resuspended in HBSS. This washing was repeated three times, and the cells were finally suspended in Dulbecco's modified Eagle's medium (DMEM) containing $10 \%$ fetal bovine serum (FBS), $70 \mathrm{mg} / 1$ streptomycin, $139 \mathrm{mg} / 1$ penicillin, $2 \mathrm{~g} / 1$ bovine serum albumin (BSA), $1 \mu \mathrm{M}$ dexamethasone, and $1 \mu \mathrm{M}$ insulin. The cell suspension $\left(1.0 \times 10^{5}\right.$ viable cells $\left./ \mathrm{cm}^{2}\right)$ was cultured in 24 -well plates that had been coated with type I collagen (Nitta Gelatin, Osaka, Japan). The cells were cultured for $3 \mathrm{~h}$ after inoculation under $5 \% \mathrm{CO}_{2}$ at $37^{\circ} \mathrm{C}$. The medium was then replaced with fresh DMEM containing $70 \mathrm{mg} / 1$ streptomycin, $139 \mathrm{mg} / \mathrm{l}$ penicillin, $2 \mathrm{~g} / 1 \mathrm{BSA}$, and the cells were cultured for $24 \mathrm{~h}$ under $5 \% \mathrm{CO}_{2}$ at $37^{\circ} \mathrm{C}$.

Cloning of Rat Octn2 Promoter The 5'-region of the rOctn2 gene was PCR-amplified with genomic DNA prepared from rat liver as a template, using upstream primer $p-4498$, downstream primer $p+138$ (see Table 1; both synthesized by Hokkaido System Science Co., Ltd.), Ex Taq DNA polymerase (Takara Shuzo Co., Ltd.), and LA Taq DNA polymerase (Takara Shuzo Co., Ltd.), based on the reported rOctn2 gene sequence (GenBank accession number NM_019269). All amplified fragments were sequenced and confirmed not to have any mutation. The finally obtained nuclear base sequence for the promoter region of rOctn2 was submitted to GeneBank (accession number AB333804). Since the upstream and downstream primers are designed to include an internal $M l u \mathrm{I}$ restriction site and an internal XhoI site, respectively, the resulting PCR products were digested with $M l u \mathrm{I}$ and $X h o \mathrm{I}$, and ligated into the luciferase reporter gene vector pGL3-Basic (Promega, Madison, WI, U.S.A.). The deletion mutant luciferase reporter plasmids were similarly constructed by PCR using specific primers.

Transfections and Luciferase Assay Since the upstream and downstream primers are designed to include an internal $M l u \mathrm{I}$ restriction site and an internal XhoI site, respectively, the resulting PCR products were digested with $M l u \mathrm{I}$ and $X h o \mathrm{I}$ and ligated into the luciferase reporter gene vector pGL3-Basic (Promega). Reporter gene constructs were transfected using LipofectAmine 2000 (Invitrogen) according to the manufacturer's protocol. Briefly, cells were plated in 24-well plates at approximately $0.5 \times 10^{5}$ cells per well for $24 \mathrm{~h}$ before transfection. Before addition of DNA/liposome complexes, the cells were rinsed with serum-free medium. For each transfection, reporter constructs $(0.8 \mu \mathrm{g})$ were cotransfected with $0.08 \mu \mathrm{g}$ of pRL-TK vector (Promega), which includes the TK promoter and Renilla luciferase as an internal control in $0.5 \mathrm{ml}$ of serum-free medium by incubation at $37^{\circ} \mathrm{C}$ for $6 \mathrm{~h}$. After $6 \mathrm{~h}$, the culture medium was changed to medium containing $10 \% \mathrm{FBS}$, and the cells were further incubated for $48 \mathrm{~h}$ at $37^{\circ} \mathrm{C}$, rinsed twice with phosphate-buffered saline, and harvested using passive lysis buffer (Promega). For luciferase assays, cell extracts were mixed with luciferase assay reagent (Promega) for detection in a luminometer (Berthold Technologies GmbH \& Co., KG, Wildbad, Germany). Relative luciferase activities were obtained as the ratio of firefly/Renilla luciferase activities, and the results were presented as the mean \pm S.E.M. of 4 to 7 independent transfection experiments.

Semi-quantitative Reverse Transcription Polymerase Chain Reaction Total RNA was prepared from the rat hepatocytes using ISOGEN (Wako Pure Chemical Industries). The total RNA content was determined by measuring the absorbance at $260 \mathrm{~nm}$. The mRNA level of rat hepatocytes was analyzed using semi-quantitative reverse transcription polymerase chain reaction (RT-PCR). Single-strand cDNAs were constructed using an oligo(dT) primer (Invitrogen) and Improm-II ${ }^{\mathrm{TM}}$ reverse transcriptase (Promega). These cDNAs provided templates for PCRs using specific primers (Table 1 ); the conditions were denaturation at $94^{\circ} \mathrm{C}$ for $30 \mathrm{~s}$, annealing at $58-62^{\circ} \mathrm{C}$ for $30-60 \mathrm{~s}$, and elongation at $72^{\circ} \mathrm{C}$ for $30 \mathrm{~s}$ in the presence of deoxynucleotides (dNTPs) and Ex Taq 
Table 1. Sequences of Oligonucleotides Used for Chimeric Plasmid Construction, PCR and Gel Mobility Shift Assay

\begin{tabular}{cl}
\hline \hline Oligonucleotides & \multicolumn{1}{c}{ Sequences (5' to $3^{\prime}$ ) } \\
\hline $\begin{array}{c}\text { Octn2 promoters } \\
\text { p }-4498\end{array}$ & ACGCGTGTCGGCCCGGAGATCTCTA \\
$\mathrm{p}-4067$ & ACGCGTGAAACCACTAAGACAAGGAGA \\
$\mathrm{p}-3039$ & ACGCGTGGACCTAGCAAGCATTGAA \\
$\mathrm{p}-2618$ & ACGCGTGCGCCTCACGAGGTTC \\
$\mathrm{p}-1770$ & ACGCGTACCATGCCTTCCCAGAGTG \\
$\mathrm{p}-570$ & ACGCGTCACTACATCTCTCTGAACCAC \\
$\mathrm{p}+138$ & CTCGAGCCGTCCTCAGCCTCCCACA \\
For quantitation & \\
Octn1 & ACCTCAGTGGGTTACTTTGCTC \\
Octn2 & GGTAGAGCTCAGCAGTGAAGAC \\
AGAAGCCTCAGTCGCACCA \\
T3PDH & CAACCCCATGCAAGTTAGGAG \\
TTGATCAAGCCTTTGCCGAAA \\
Gel shift assay & GGTGGACCTCATGGCCTACA \\
PerPPAR $\alpha$ & GGGACCAGGACAAAGGTCACGTTCCGGATC \\
PPRE0 & AAAGTCTTCTTGTGTCCAAGGCCAG \\
\hline
\end{tabular}

polymerase (Takara Shuzo Co., Ltd.). Annealing time and temperature were changed as required depending on the genes. The PCR cycle numbers were titrated for each primer pair to confirm that amplification was performed within the linear range. PCR products were analyzed by $2 \%$ agarose gel $(\mathrm{w} / \mathrm{v})$ electrophoresis and the gels were stained with ethidium bromide for visualization. mRNA levels were quantified by using light capture (Atto Co., Tokyo). PCR amplification data were normalized with respect to glyceraldehyde-3-phosphate dehydrogenase (G3PDH). The quantitation of each gene was repeated at least three times using RNA sources isolated from independently cultured cells.

Northern Blot Analysis Total RNA was prepared from the liver by the acid guanidium thiocyanate-phenol chloroform extraction method. ${ }^{23)}$ Northern blot analysis was carried out essentially as described previously. ${ }^{24)}$ The probe used was the region of 1058 - $1283 \mathrm{bp}$ of mouse Octn2.

Gel Mobility Shift Assay Nuclear extracts were prepared from rat hepatocyte as described previously. ${ }^{25)}$ Protein concentration was measured by the method of Bradford ${ }^{26)}$ using a protein assay kit (Bio-Rad, Inc., Hercules, CA, U.S.A.). Oligonucleotides of the sense and antisense strands containing putative PPAR $\alpha$ binding sites were synthesized. The sequences of the oligonucleotides are shown in Table 1 and mapped on the Octn2 promoter sequence. Gel mobility shift assay was carried out as described previously. ${ }^{25}$ The PPAR $\alpha$ specific antibodies were obtained commercially from Santa Cruz Biotechnology Inc. (Santa Cruz, CA, U.S.A.).

Measurement of Uptake by Freshly Isolated Hepatocytes For the uptake measurements, hepatocytes were isolated from the livers of male Wistar rats. Freshly isolated hepatocytes were suspended in uptake medium containing $118 \mathrm{~mm} \mathrm{NaCl}, 24 \mathrm{M} \mathrm{NaHCO}_{3}, 4.8 \mathrm{~mm} \mathrm{KCl}, 5.0 \mathrm{~mm}$ D-glucose, $1.5 \mathrm{~mm} \mathrm{CaCl}_{2} 2 \mathrm{H}_{2} \mathrm{O}, 0.96 \mathrm{~mm} \quad \mathrm{KH}_{2} \mathrm{PO}_{4}, 1.2 \mathrm{~mm} \mathrm{MgSO}_{4}$ $7 \mathrm{H}_{2} \mathrm{O}$, and $24 \mathrm{~mm}$ HEPES, adjusted to $\mathrm{pH} 7.3$. The cell suspension was preincubated at $37^{\circ} \mathrm{C}$ for $20 \mathrm{~min}$ in the uptake medium, then centrifuged, and the resultant cell pellets were mixed with the uptake medium containing $\left[{ }^{3} \mathrm{H}\right]$ carnitine. At
(A)

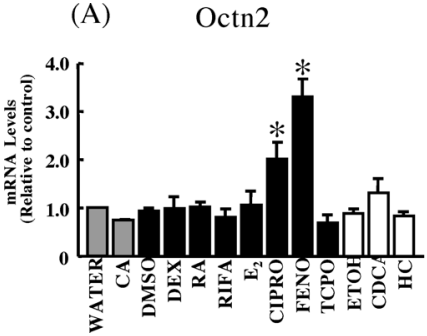

(B)

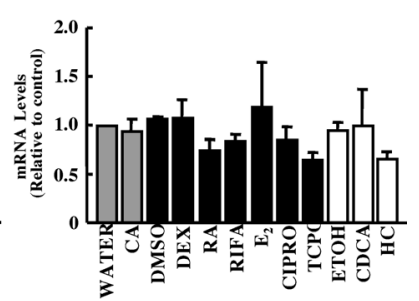

Fig. 1. Induction of rOctn2 mRNA by Ligands of Nuclear Receptors in Primary-Cultured Rat Hepatocytes

Primary-cultured rat hepatocytes were treated with ligands of several nuclear receptors: cholic acid (CA, $100 \mu \mathrm{M})$, chenodeoxycholic acid (CDCA, $200 \mu \mathrm{M})$, ciprofibrate (CIPRO, $100 \mu \mathrm{M})$, dexamethasone (DEX, $100 \mu \mathrm{M}$ ), estradiol $\left(\mathrm{E}_{2}, 100 \mu \mathrm{M}\right)$, fenofibrate (FENO, $100 \mu \mathrm{M}), 22(R)$-hydroxycholesterol $(\mathrm{HC}, 30 \mu \mathrm{M})$, all-trans retinoic acid (RA $100 \mu \mathrm{M}$ ), rifampin (RIFA, $100 \mu \mathrm{M}$ ), and TCPOPOB (TCPO, $5 \mu \mathrm{M}$ ) for $12 \mathrm{~h}$. Each ligand was dissolved in water (open columns), $0.1 \%$ ethanol (dotted columns) or $0.1 \%$ dimethyl sulfoxide (DMSO, closed columns). Semi-quantitative RT-PCR was performed with total RNA extracted from primary-cultured rat hepatocytes. PCR products were electrophoresed on $2 \%$ agarose gel and stained with ethidium bromide. mRNA levels of rOctn2 (A) and rOctn1 (B) were normalized by the expression level of G3PDH. Each point represents the mean \pm S.E.M. from three to seven experiments. (*) indicates a significant difference from the control (Student's $t$-test, $p<0.05$ ).

appropriate times, aliquots of the mixture were withdrawn and the cells were separated from the uptake medium by centrifugation through a layer of a mixture of silicone oil (SH550; Toray Dow Corning Co., Tokyo, Japan) and liquid paraffin (Wako Pure Chemical Industries) at the ratio of $10: 3$ (density, 1.03) on $3 \mathrm{~m} \mathrm{KOH}$ solution. Each cell pellet was solubilized in $3 \mathrm{~N} \mathrm{KOH}$ and then neutralized with $\mathrm{HCl}$. The cell-associated radioactivity was measured with a liquid scintillation counter using Cleasol-1 as a liquid scintillation fluid (Nacalai Tesque, Kyoto, Japan).

Statistical Analysis The statistical significance of differences was determined by using Student's $t$-test with $p<0.05$ as the criterion. Data are shown as the mean \pm standard error of the mean (S.E.M.).

\section{RESULTS}

Expressional Regulation of rOctn2 Primary-cultured rat hepatocytes were exposed to ligands of various nuclear receptors, and the expression of rOctn1 and rOctn2 was quantitated (Fig. 1). rOctn2 mRNA level was significantly increased by exposure to ciprofibrate and fenofibrate in the primary-cultured rat hepatocytes, while that of rOctn1 was not changed (Fig. 1). Time $(6-48 \mathrm{~h})$ and concentration (10$500 \mu \mathrm{M})$ dependences of the effect of fenofibrate on the induction of the expression of rOctn2 were examined. It was found that the mRNA level of rOctn2 was maximally increased by exposure of the cells to $100 \mu \mathrm{M}$ fenofibrate for $12 \mathrm{~h}$ (Fig. 2). Other nuclear receptor ligands examined in this study did not affect the expression level of rOctn2.

Effect of PPAR $\alpha$ Antagonist MK886 on the Expression of rOctn2 To examine the mechanism of the increase of rOctn2 expression by fenofibrate treatment, the effect of the $\operatorname{PPAR} \alpha$ antagonist MK886 on the action of fenofibrate was studied (Fig. 3). When fenofibrate and MK886 were used simultaneously, the extent of the fenofibrate-induced increase of mRNA levels of rOctn2 was decreased in a MK886 dosedependent manner. The mRNA level of rat carnitine palmitoyltransferase (rCPT) 1A, which is also regulated by PPAR $\alpha,{ }^{27)}$ was similarly decreased (Fig. 3). These results 

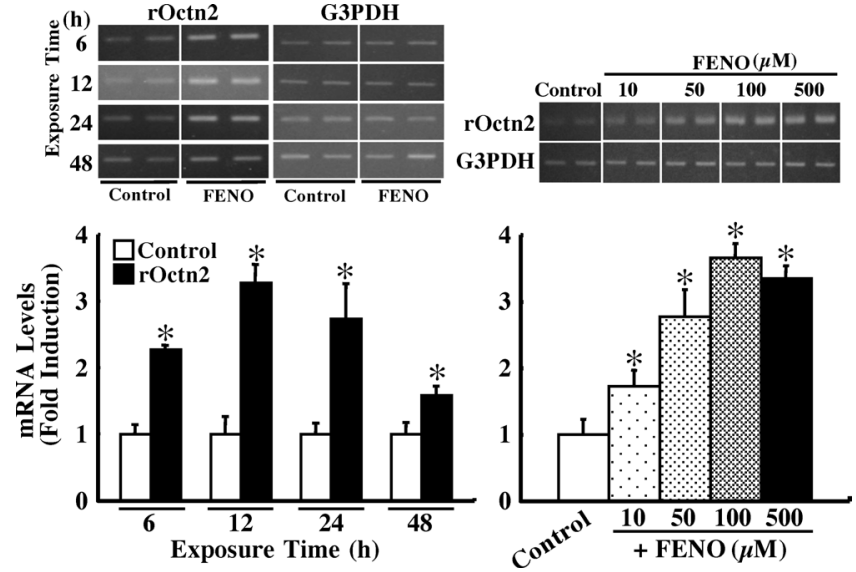

Fig. 2. Time and Dose Dependences of Induction of rOctn2 mRNA by Fenofibrate in Primary-Cultured Rat Hepatocytes

Primary-cultured rat hepatocytes were treated with fenofibrate at $10-500 \mu \mathrm{M}$ for 6 to $48 \mathrm{~h}$. Semi-quantitative RT-PCR was performed with total RNA extracted from the hepatocytes. PCR products were electrophoresed on $2 \%$ agarose gel and stained with ethidium bromide. mRNA levels of rOctn2 were normalized by the expression level of $\mathrm{G} 3 \mathrm{PDH}$. Each point represents the mean \pm S.E.M. from four experiments. (*) indicates a significant difference from the control (Student's $t$-test, $p<0.05$ ).
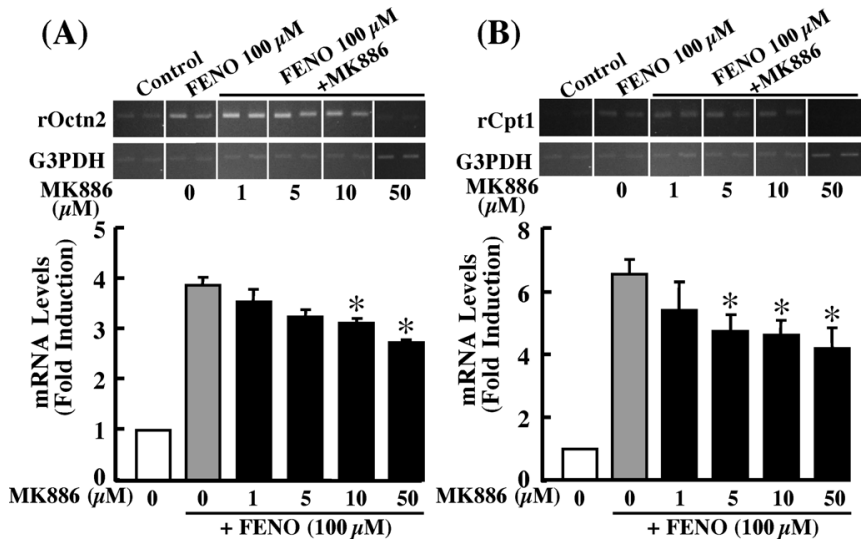

Fig. 3. Inhibitory Effect of MK886 on Fenofibrate-Induced Expression of rOctn2 and rCpt1A mRNA in Primary-Cultured Rat Hepatocytes

Primary-cultured rat hepatocytes were treated with DMSO (open bars), fenofibrate alone (dotted bars) or MK886 and fenofibrate (closed bars). Semi-quantitative RT-PCR was performed with total RNA extracted from primary-cultured rat hepatocytes. PCR products were electrophoresed on $2 \%$ agarose gel and stained with ethidium bromide. mRNA levels of rOctn2 (A) and rCpt1 (B) were normalized by the expression level of G3PDH. Each point represents the mean \pm S.E.M. from four experiments. (*) indicates a significant difference from fenofibrate treated alone (Student's $t$-test, $p<0.05$ ).

suggested that PPAR $\alpha$ is involved in the effect of fenofibrate on rOctn 2 expression.

Effect of Over-Expression of PPAR $\alpha$ on the Expression of rOctn2 The involvement of PPAR $\alpha$ in the expression of rOctn2 was further examined by studying the effect of overexpression of PPAR $\alpha$. The rOctn2 mRNA level was significantly increased by exposure to fenofibrate, both in PPAR $\alpha$ overexpressing cells and empty vector-transfected cells, in comparison with cells treated with dimethyl sulfoxide (DMSO) (Fig. 4). A further increase of rOctn2 mRNA level was observed in PPAR $\alpha$ over-expressing cells in comparison with that in empty-vector transfected cells. Since the expression of Octn 2 was increased by $\operatorname{PPAR} \alpha$ over-expression and by fenofibrate treatment in primary-cultured rat hepatocytes, involvement of PPAR $\alpha$ in regulation of the rOctn2 gene was confirmed.
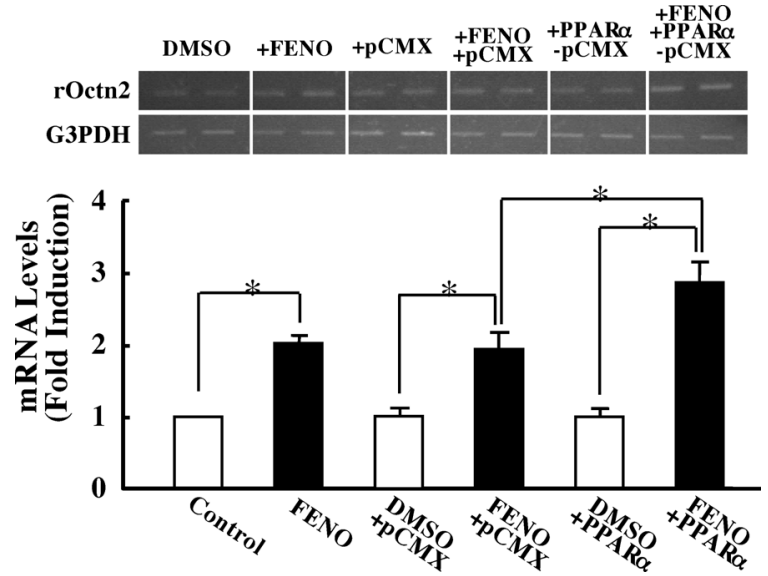

Fig. 4. Effect of Over-Expression of $\operatorname{PPAR} \alpha$ on rOctn2 mRNA Expression in Primary-Cultured Rat Hepatocytes

Primary-cultured rat hepatocytes were transfected with the mPPAR $\alpha$-expression plasmid or with the empty vector as a control. Semi-quantitative RT-PCR was performed with total RNA extracted from the hepatocytes. PCR products were electrophoresed on $2 \%$ agarose gel and stained with ethidium bromide. mRNA levels of rOctn2 were normalized by the expression level of G3PDH. Each point represents the mean \pm S.E.M. from four experiments. $(*)$ indicates a significant difference from each control (Student's $t$-test, $p<0.05$ )

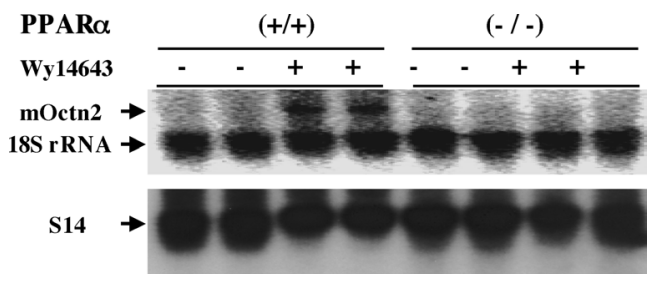

Fig. 5. Influence of PPAR $\alpha$ on Wy14643-Mediated Induction of mOctn2 mRNA

Wild-type PPAR $\alpha(+/+)$ and PPAR $\alpha$ null $(-/-)$ mice were fed with $(+)$ or without (-) $0.1 \%$ Wy14643. Total RNA from individual hepatocytes was analyzed by Northern blotting. S14 indicates loading control.

Induction of mOctn2 by PPAR Ligand in PPAR $\alpha$-Null Mice To directly examine the role of $\operatorname{PPAR} \alpha$ in the induction of mOctn 2 mRNA, we utilized PPAR $\alpha$-null mice. ${ }^{25)}$ Northern blot analyses of liver RNA from PPAR $\alpha(+/+)$ and $\operatorname{PPAR} \alpha(-/-)$ mice fed with or without $0.1 \%$ Wy14643 are shown in Fig. 5. In the wild-type PPAR $\alpha(+/+)$ mice, the expression of mOctn2 was increased by Wy14643, while such an increase was not observed in the PPAR $\alpha(-/-)$ mice (Fig. 5).

Localization of the Transcriptional Initiation Site of the rOctn2 Gene To further examine whether PPAR $\alpha$ is directly involved in the transcriptional regulation of rOctn2, we tried to identify the peroxisome proliferator response element (PPRE) in the rOctn2 promoter. First, we determined the transcription start site of rOctn2 using the $5^{\prime}$-RACE method (data not shown). The obtained sequences suggested that the transcription initiation site was $20 \mathrm{bp}$ upstream from the start site of the published rOctn 2 cDNA sequences. There are 5 putative PPREs in the rOctn2 promoter region up to 4498 bp (Fig. 6, Table 2).

Next, we constructed six luciferase reporter plasmids $(\mathrm{p}-570, \mathrm{p}-1770, \mathrm{p}-2618, \mathrm{p}-3039, \mathrm{p}-4067$ and $\mathrm{p}-4498)$ (Fig. 6A). All the reporter gene plasmid constructs other than p-4067 exhibited increased transcriptional activity in response to fenofibrate. Among them, the shortest p-570 ex- 


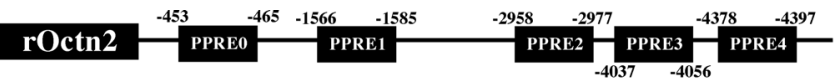

(A)

(B)
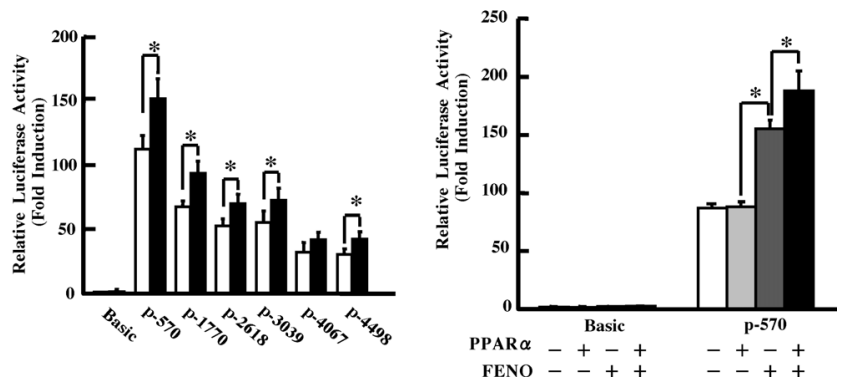

Fig. 6. Effect of PPAR $\alpha$ and Fenofibrate on rOctn2 Promoter Activity in Fao Cells

Fao cells were cultured in either the absence (open bars) or presence of fenofibrate $(100 \mu \mathrm{M})$ (closed bars) for $12 \mathrm{~h}$ before harvesting (A). The cells were co-transfected with rOctn 2 reporter-gene constructs together with $\operatorname{PPAR} \alpha$ expression vectors and/or empty vector, and cultured in the absence or presence of fenofibrate $(100 \mu \mathrm{M})(\mathrm{B})$. Luciferase activity is shown as the ratio of firefly/Renilla luciferase and data represent the mean \pm S.E.M. of 5 independent transfection experiments. (*) indicates a significant difference from the control (Student's $t$-test, $p<0.05$ ).

Table 2. Sequence Alignment of the Putative 5 PPREs in rOctn2 and PPRE of Rat Acyl-CoA Oxidase (PerPPRE)

\begin{tabular}{lllrr} 
Conserved & \multicolumn{2}{c}{ CAAAACTAGGTCA A AGGTCA } & & \\
\multicolumn{1}{c}{ sequence } & GG T & T & & \\
PerPPRE & GGGGACCAGGACA A AGGTCA & $5 / 7$ & $12 / 13$ \\
PPRE0 & AAGTCTTGTGTCC A AGGCCA & $3 / 7$ & $9 / 13$ \\
PPRE1 & TCACCTGAGGTCA A AGCTGT & $1 / 7$ & $10 / 13$ \\
PPRE2 & CATATATAGGCCC T AGGTTC & $5 / 7$ & $9 / 13$ \\
PPRE3 & GACAAGGAGACCA A AGGACA & $3 / 7$ & $10 / 13$ \\
PPRE4 & CAAGACTTGAGTA A AGGTCT & $6 / 7$ & $8 / 13$
\end{tabular}

The right-hand columns show the number of matches between the 7 nucleotides forming the $5^{\prime}$-flanking region and the $5^{\prime}$-consensus sequence, and the number of matches between the 13 nucleotides forming the core DR1.

hibited apparently the maximum effect, suggesting the key site may be located close to the transcription start site.

Stimulation of the rOctn2 Promoter in Fao Cells by Induced Expression of PPAR $\alpha$ To investigate the effect of exogenously expressed PPAR $\alpha$ on rOctn 2 promoter function in Fao cells, an expression plasmid coding for PPAR $\alpha$ was introduced into Fao cells together with $p-570$ reporter plasmid. As shown by closed columns in Fig. 6B, cotransfection of the PPAR $\alpha$ plasmid enhanced the fenofibrate-induced rOctn 2 promoter-driven luciferase activity 1.3-fold compared with cotransfection of the empty vector, while $\operatorname{PPAR} \alpha$ did not activate pGL3-basic (Fig. 6B).

Identification of Putative PPRE in rOctn2 Promoter To identify the composition of nuclear proteins that interact with the cis-acting motif, we performed a gel mobility shift assay. Gel mobility shift assay was conducted using rat hepatocyte-derived nuclear extracts and a putative PPRE oligonucleotide within rOctn 2 promoter. The rOctn2 promoter region from -570 to -1 nt included one putative PPRE (Fig. 6). As shown in Fig. 7, although three protein complex bands $\mathrm{A}, \mathrm{B}$, and $\mathrm{C}$ were observed using rOctn2 oligonucleotide (Fig. 7, lane 4), their signals were weak in comparison with perfect PPAR $\alpha$ (Fig. 7, lane 1) as reported previously. ${ }^{28)}$ The protein-DNA complexes shown in Fig. 7 were further analyzed using antibody directed to PPAR $\alpha$ nuclear protein (Fig. 7, lanes 3 and 7) and PPAR $\alpha$-specific oligonucleotide com-

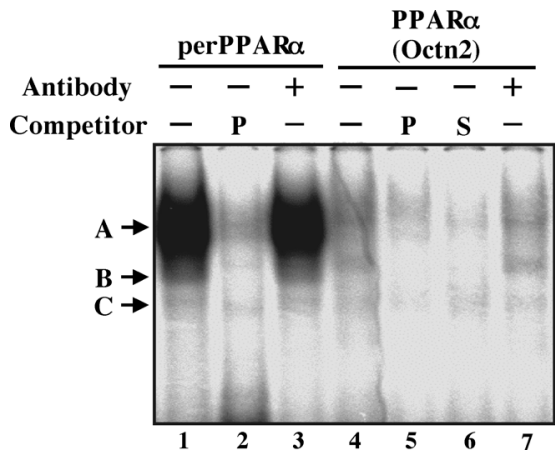

Fig. 7. Gel Mobility Shift Assay and Surper Shift Analysis of PPAR $\alpha$ Bound Protein Complex

Gel mobility shift assay was carried out with nuclear extract ( $10 \mu \mathrm{g}$ of protein) from rat primary-cultured hepatocytes. Lanes 1 and 4, probe alone; lanes 2 and 5, probe with 5 pmol of unlabeled perfect PPAR $\alpha$ oligonucleotide (P: perfect competition); lane 6 , probe with $5 \mathrm{pmol}$ of unlabeled PPAR $\alpha$ oligonucleotide (S: self competition); lanes 3 and 7, probe with PPAR $\alpha$ specific antibody (PPAR $\alpha$ antibody)
(A)

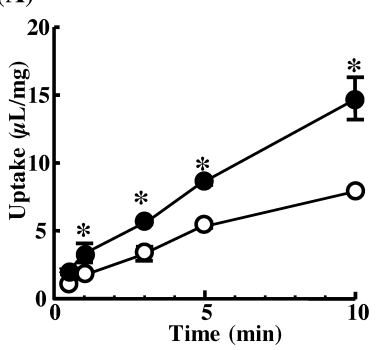

(B)

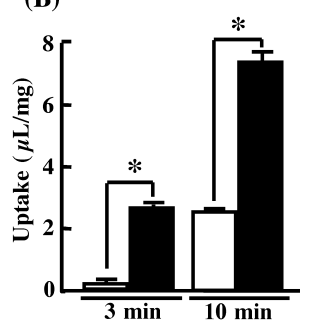

Fig. 8. Uptake of $\mathrm{L}-\left[{ }^{3} \mathrm{H}\right]$ Carnitine by Freshly Isolated Hepatocytes from Fenofibrate-Treated Rats

Uptake of $\mathrm{L}-\left[{ }^{3} \mathrm{H}\right]$ carnitine $(100 \mathrm{~nm})$ by freshly isolated hepatocytes from fenofibrate (closed circles) or mineral oil (opened circles)-treated rats for $4 \mathrm{~d}$ was measured over $10 \mathrm{~min}$ in transport buffer ( $\mathrm{pH} 7.4)$ at $37^{\circ} \mathrm{C}$. Results were obtained after subtraction of the uptake into extracellularly adhering water space, obtained as the apparent uptake of $\left[{ }^{14} \mathrm{C}\right]$ inulin $(43 \mu \mathrm{g} / \mathrm{ml})$, at each point $(\mathrm{A})$. $\mathrm{Na}^{+}$-dependent uptake of $\mathrm{L}-\left[{ }^{3} \mathrm{H}\right]$ carnitine $(100 \mathrm{~nm})$ by freshly isolated hepatocytes from fenofibrate (closed bars) or mineral oil (open bars)-treated rats for $4 \mathrm{~d}$ was measured at 3 and $10 \mathrm{~min}$ in transport buffer ( $\mathrm{pH}$ 7.4) at $37^{\circ} \mathrm{C}$. Results were obtained by subtracting the uptake of $\mathrm{L}-\left[{ }^{3} \mathrm{H}\right]$ carnitine $(100 \mathrm{nM})$ in the absence of $\mathrm{Na}^{+}$, measured in the presence of $\mathrm{NMG}^{+}(\mathrm{B})$. Each result represents the mean \pm S.E.M. $(n=3)$, and $(*)$ indicates a significant difference from the control (Student's $t$-test, $p<0.05$ ).

petitors (Fig. 7, lanes 2, 5, and 6). The binding of three shifted complexes to the rOctn 2 oligonucleotide were all subject to competition by perfect PPAR $\alpha$ oligonucleotide (Fig. 7, lanes 2 and 5), which has exactly the same sequence as PPRE, and an excess of self oligonucleotide with the same sequence as the probe oligonucleotide (Fig. 7, lane 6). Shifted complex band A was faintly detected by PPAR $\alpha$ specific antibody (Fig. 7, lanes 3 and 7).

Uptake of Carnitine by Freshly Isolated Hepatocytes from Rats Treated with Fenofibrate We next investigated the effect of fenofibrate on the hepatic uptake of carnitine by freshly isolated hepatocytes obtained from fenofibrate-treated rats. Initial studies determined that the uptake of $\left[{ }^{3} \mathrm{H}\right]$ carnitine $(100 \mathrm{nM})$ increased linearly for $10 \mathrm{~min}$. In addition, $\mathrm{Na}^{+}-$ dependent uptake activity of $\left[{ }^{3} \mathrm{H}\right]$ carnitine was increased in fenofibrate-treated rats in comparison with untreated rats (Fig. 8). Furthermore, the mRNA level of rOctn2 was increased 5.2-fold in fenofibrate-treated rats (data not shown). Accordingly, PPAR $\alpha$ is likely to be involved in the functional regulation of carnitine uptake by liver via Octn2. 


\section{DISCUSSION}

We previously found that OCTN2, cloned as a homologue of the organic cation transporter OCTN1, transports carnitine in a high-affinity and $\mathrm{Na}^{+}$-dependent manner. ${ }^{2)}$ Furthermore, mutations of OCTN2 are directly related to systemic carnitine deficiency in humans as well as in mice, ${ }^{4)}$ demonstrating that OCTN2 is a physiologically important transporter of carnitine. Therefore, in this study, we investigated the regulatory mechanisms of rat Octn2 expression, focusing on the nuclear receptors.

We initially treated primary-cultured rat hepatocytes with ligands of various nuclear receptors. The PPAR $\alpha$ ligands ciprofibrate and fenofibrate significantly increased the expression of the rOctn2 gene, but not that of rOctn1 (Fig. 1). Accordingly, it was suggested that the expression of rOctn2 could be regulated by PPAR $\alpha$, as is the case for genes associated with $\beta$-oxidation in mitochondria. ${ }^{29}$ Since the expression of rOctn 2 was not affected by $22(R)$-hydroxycholesterol (HC), an $\operatorname{LXR} \alpha$ ligand that regulates hepatic peroxisomal fatty acid $\beta$-oxidation, ${ }^{30)}$ it was thought that rOctn 2 might not be associated with hepatic peroxisomal $\beta$-oxidation of fatty acids.

Then, we examined whether the effect of fenofibrate on Octn 2 expression was mediated directly by $\operatorname{PPAR} \alpha$ by using the $\operatorname{PPAR} \alpha$ antagonist MK886, $\operatorname{PPAR} \alpha$-over-expressing cells, and PPAR $\alpha$-knockout mice. The involvement of $\operatorname{PPAR} \alpha$ was suggested by the observation that the Octn2 mRNA level was increased by over-expression of PPAR $\alpha$ (Fig. 4). Octn 2 mRNA was increased in wild-type PPAR $\alpha$ $(+/+)$ mice fed with Wy14643, while such an effect was not observed in PPAR $\alpha(-/-)$ mice (Fig. 5). Therefore, our findings indicate that rOctn2 expression in liver is regulated by $\operatorname{PPAR} \alpha$.

To examine whether the expression of $\operatorname{rOctn} 2$ by $\operatorname{PPAR} \alpha$ was regulated directly or indirectly, the presence of conserved PPAR $\alpha$ binding sites (PPRE) was investigated in the promoter region of $\mathrm{rOctn} 2 .{ }^{29)} \mathrm{We}$ found 5 putative sequences that correspond to PPRE in the rat Octn2 promoter region up to $-5 \mathrm{~kb}$ (Fig. 6, Table 2). Co-expression of exogenous $\operatorname{PPAR} \alpha$ stimulated rOctn 2 promoter activity up to 1.3 -fold with the $p-570$ reporter plasmid in Fao cells (Fig. 6B). However, the increase of rOctn2 promoter activity in $\operatorname{PPAR} \alpha$-over-expressing cells was lower than that of the Octn 2 mRNA level increased by over-expression of PPAR $\alpha$ (Figs. 4, 6B). In addition, binding of PPAR $\alpha$ to PPRE0 that is a proximal PPRE of the rOctn2 promoter was confirmed by both gel mobility shift assays and supershift analysis using an anti-PPAR $\alpha$ antibody (Fig. 7). The results shown in Fig. 7 demonstrated that three protein complex bands A, B, and $\mathrm{C}$ were detected using rOctn2 oligonucleotide (Fig. 7, lane 4 ). Since the signals of three protein complex bands were weak in comparison with perfect PPAR $\alpha$ (Fig. 7, lane $1)^{28)}$ and the shifted complex band A was only faintly observed by $\operatorname{PPAR} \alpha$ specific antibody (Fig. 7, lanes 3 and 7), the contribution of the proximal PPRE (PPRE0) to the promoter activity of rOctn2 might not be high. In Table 2, we aligned the sequences of the 5 putative PPREs in rOctn 2 and the PPRE of rat acyl-CoA oxidase gene as a function of PPAR binding, with the top element as the strongest binder, and scored the number of identities between each element and the consensus sequence given at the top of Table 2. This consensus sequence is formed of two main parts, $13 \mathrm{nu}-$ cleotides composing a perfect DR1, which consists of two directly repeating 6-bp half-sites spaced by a nucleotide (AGGTCA(A/T)AGGTCA), and 7 nucleotides corresponding to the $5^{\prime}$-flank consensus. ${ }^{31)}$ The PPAR $\alpha$ binding activity for the studied PPRE in the rOctn2 promoter might not be high, ${ }^{29)}$ so it is also possible that the PPRE might be located beyond the promoter region examined in the present study and/or the promoter may contain an unknown PPRE.

It has been shown that treatment of rats with clofibrate increases the concentration of carnitine in the liver, ${ }^{32)}$ and it was suggested that this effect is caused by increased hepatic carnitine synthesis due to an increased availability of trimethyllysine from muscle. ${ }^{33)}$ The present study shows that the increase of the expression level of rOctn2 by fenofibrate led to an increase of $\left[{ }^{3} \mathrm{H}\right]$ carnitine uptake activity in liver (Fig. 8). Therefore, up-regulation of rOctn2 enhanced carnitine uptake from blood into liver cells, and this is one reason for the increased carnitine concentration in liver of rats treated with clofibrate. ${ }^{32)}$

In conclusion, treatment of rat hepatocytes with the $\operatorname{PPAR} \alpha$ agonist fenofibrate induces rOctn 2 mRNA. The dependence of rOctn 2 gene expression on $\operatorname{PPAR} \alpha$ was confirmed in experiments with a PPAR $\alpha$ antagonist, PPAR $\alpha$ over-expressing cells, and PPAR $\alpha$-null mice. These findings provide novel evidence for $\operatorname{PPAR} \alpha$-dependent regulation of rOctn2, and improve our understanding of the role of rOctn2 in lipid metabolism.

Acknowledgement This study was supported in part by a Grant-in-Aid for Scientific Research from The Ministry of Education, Culture, Sports, Science and Technology of Japan.

\section{REFERENCES}

1) Yabuuchi H., Tamai I., Nezu J., Sakamoto K., Oku A., Shimane M., Sai Y., Tsuji A., J. Pharmacol. Exp. Ther., 289, 768-773 (1999).

2) Tamai I., Ohashi R., Nezu J., Yabuuchi H., Oku A., Shimane M., Sai Y., Tsuji A., J. Biol. Chem., 273, 20378 -20382 (1998).

3) Tamai I., Ohashi R., Nezu J., Sai Y., Kobayashi D., Oku A., Shimane M., Tsuji A., J. Biol. Chem., 275, 40064-40072 (2000).

4) Nezu J., Tamai I., Oku A., Ohashi R., Yabuuchi H., Hashimoto N., Nikaido H., Sai Y., Koizumi A., Shoji Y., Takada G., Matsuishi T., Yoshino M., Kato H., Ohura T., Tsujimoto G., Hayakawa J., Shimane M., Tsuji A., Nat. Genet., 21, 91-94 (1999).

5) Yokogawa K., Higashi Y., Tamai I., Nomura M., Hashimoto N., Nikaido H., Hayakawa J., Miyamoto K., Tsuji A., J. Pharmacol. Exp. Ther., 289, 224-230 (1999).

6) Tamai I., China K., Sai Y., Kobayashi D., Nezu J., Kawahara E., Tsuji A., Biochim. Biophys. Acta, 1512, 273-284 (2001).

7) Tamai I., Nakanishi T., Kobayashi D., China K., Kosugi Y., Nezu J. Sai Y., Tsuji A., Mol. Pharm., 1, 57-66 (2003).

8) Wu X., George R. L., Huang W., Wang H., Conway S. J., Leibach F. H., Ganapathy V., Biochim. Biophys. Acta, 1466, 315-327 (2000).

9) Enomoto A., Wempe M. F., Tsuchida H., Shin H. J., Cha S. H., Anzai N., Goto A., Sakamoto A., Niwa T., Kanai Y., Anders M. W., Endou H., J. Biol. Chem., 277, 36262-36271 (2002).

10) Nakanishi T., Hatanaka T., Huang W., Prasad P. D., Leibach F. H., Ganapathy M. E., Ganapathy V., J. Physiol., 532, 297-304 (2001).

11) Bremer J., Physiol. Rev., 63, 1420-1480 (1983).

12) Treem W. R., Stanley C. A., Finegold D. N., Hale D. E., Coates P. M., N. Engl. J. Med., 319, 1331-1336 (1988).

13) Nishimura M., Naito S., Yokoi T., Drug Metab. Pharmacokinet., 19, 135-149 (2004). 
14) Schoonjans K., Staels B., Auwerx J., J. Lipid. Res., 37, 907-925 (1996).

15) Kostadinova R., Wahli W., Michalik L., Curr. Med. Chem., 12, 29953009 (2005).

16) Kramer J. A., Blomme E. A., Bunch R. T., Davila J. C., Jackson C. J., Jones P. F., Kolaja K. L., Curtiss S. W., Toxicol. Pathol., 31, 417-431 (2003).

17) Mandard S., Müller M., Kersten S., Cell Mol. Life Sci., 61, 393-416 (2004).

18) Luci S., Geissler S., Konig B., Koch A., Stabgl G. I., Hirche F., Eder K., Biochem. Biophys. Res. Commun., 350, $704-708$ (2006).

19) Motojima K., Passilly P., Peters J. M., Gonzalez F. J., Latruffer N., J. Biol. Chem., 273, 16710-16714 (1998).

20) Kliewer S. A., Forman B. M., Blumberg B., Ong E. S., Borgmeyer U., Mangelsdore D. J., Umesono K., Evans R. M., Proc. Natl. Acad. Sci. U.S.A., 91, 7355-7359 (1994).

21) Lee S. S., Pineau T., Drago J., Lee E. J., Owens J. W., Kroetz D. L., Fernandez-Salguero P. M., Westphal H., Gonzalez F. J., Mol. Cell Biol., 15, 3012-3022 (1995).

22) Tamai I., Tsuji A., J. Pharmacobio-Dyn., 10, 632-638 (1987).

23) Chomczynski P., Sacchi N., Anal. Biochem., 162, 156-159 (1987).
24) Motojima K., Peter J. M., Gonzalez F. J., Biochem. Biophys. Res. Commun., 230, 155-158 (1997).

25) Maeda T., Mazzulli J. R., Farrance A. F., Stewart A. F. R., J. Biol. Chem., 277, 24346-24352 (2002).

26) Bradford. M., Anal. Biochem., 72, 248-254 (1976).

27) Louet J. F., Chatelain F., Decaux J. F., Park E. A., Kohl C., Pineau T., Girard J., Pegorier J. P., Biochem. J., 354, 189-197 (2001).

28) Schoonjans K., Watanabe M., Suzuki H., Mahfoudi A., Krey G., Wahli W., Grimaldi P., Staels B., Yamamoto T., Auwerx J., J. Biol. Chem., 270, 19269-19276 (1995).

29) Juge-Aubry C., Pernin A., Favez T., Burger A. G., Wahli W., Meier C. A., Desvergne B., J. Biol. Chem., 272, 25252-25259 (1997).

30) Hu T., Foxworthy P., Siesky A., Ficorilli J. V., Gao H., Li S., Christe M., Ryan T., Cao G., Eacho P., Michael D. M., Michael L. F., Endocrinology, 146, 5380 - 5387 (2005).

31) Palmer C. N., Hsu M.-H., Griffin K. J., Johnson E. F., J. Biol. Chem., 270, 16114-16121 (1995).

32) Paul H. S., Adibi S. A., J. Clin. Invest., 64, 405-412 (1979).

33) Paul H. S., Gleditsch C. E., Adibi S. A., Am. J. Physiol., 14, E311E315 (1986) 